УДК : 94(94+477)

\title{
ПЕРШІ УКРАЇНЦІ В АВСТРАЛІЇ
}

\section{Перга Тетяна Юріївна}

Надіслано:

10.02.2020

кандидат історичних наук, старший науковий співробітник, Рецензовано:

ДУ «Інститут всесвітньої історії НАН України», 03.03.2020 м. Київ, Україна Прийнято: ORCID: 0000-0002-8725-3451 15.03 .2020 pergatatiana@gmail.com

Мета статті полягає у вивченні історії переселення на австралійський континент перших українців. Хронологічні рамки дослідження: поч. ХІХст. 40-і pp. XX ст.; воно проведено на основі аналізу вітчизняних і зарубіжних розвідок та енциклопедичних матеріалів. У результаті дослідження узагальнено існуючі фрагментарні дані щодо чисельності та зайнятості українців, які прибували в Австралію у вказаний період. Зроблено висновок, що їх доцільно вважати першою хвилею міграції українців на цю територію. Виявлено, що вона була малочисельною, а перші українці в Австралії переважно займалися сільськогосподарською діяльністю. Розкрито головні шляхи прибуття українців на австралійський континент: із Західної України через Європу та зі Східної України через Далекий Схід і Китай. Зроблено висновок, що найбільш відомим українцем, який зробив значний внесок у дослідження Австралії і Океанії, $є$ М. Миклухо-Маклай. Спростовано твердження російських дослідників про російське походження вченого; на противагу, доведено його українське походження. Розглянуто головні здобутки науковця, серед яких не лише наукове доведення однакової біологічної повноцінності людей усіх націй і рас, а й виступ проти расизму та колоніалізму, прагнення домогтися від російського уряду взяти під контроль ці території. Крім цього, М. Миклухо-Маклай намагався заохотити європейців до переїзду на постійне місце проживання у Нову Гвінею і відвідав 3 цією метою Київ, Одесу, Петербург і Москву. Виявлено перспективи подальших досліджень у цій царині, зокрема, це економічна діяльність і побут перших українців в Австралії.

Ключові слова: Австралія; українці; Океанія; М. Миклухо-Маклай. 
Perha Tetiana, Candidate of Historical Sciences, Senior Research Fellow, State Institution "Institute of World History of the National Academy of Sciences of Ukraine", Kyiv, Ukraine

\section{The First Ukrainians in Australia}

The purpose of the article is to investigate the history of the migration of the first Ukrainians to the Australian continent. Chronological framework of the research is the beginning of the XIX century - the 40s of the XX century; it is based on the analysis of Ukrainian and foreign studies and encyclopedic materials. As a result of the study, existing fragmentary data on the number and employment of Ukrainian people arriving to Australia during this period is summarized. It is concluded that they should be considered the first wave of Ukrainian migration on this territory. It is revealed that it was a small in number, and its members were mainly engaged in agricultural activities. The main routes of the Ukrainians' arrival to the Australian continent are revealed: from the Western Ukraine through Europe and from the Eastern Ukraine through the Far East and China. It is concluded that the most famous Ukrainian who made a significant contribution to the investigation of Australia and Oceania is M. Myklukho-Maklay. The statement of the Russian researchers about the Russian origin of the scientist was refuted; in contrast, its Ukrainian origin was proved. The main achievements of the researcher are considered. They are the following: scientific evidence of the equal biological usefulness of people of all nations and races as well as fight against racism and colonialism, and lobbing the control of these territories by Russia. In addition, M. Myklukho-Maklay tried to attract Europeans for the permanent residence in New Guinea and visited Kiev, Odessa, Petersburg and Moscow for this purpose. The prospects for further research in this area were identified; in particular, it is the economic activity and everyday life of the first Ukrainians in Australia.

Key words: Australia; Ukrainians; Oceania; M. Myklukho-Maclay.

Перга Татьяна Юрьевна, кандидат исторических наук, старший научный сотрудник, ГУ «Институт всемирной истории НАН Украины», 2. Киев, Украина

\section{Первые украинцы в Австралии}

Цель статьи заключается в изучении истории переселения на австралийский континент первых украинцев. Хронологические рамки исследования: нач. XIX в. - 40-е гг. XX в.; оно проведено на основе анализа отечественных и зарубежных исследований и энциклопедических материалов. В результате исследования обобщены существующие фрагментарные данные о численности и занятости украинцев, прибывающих в Австралию в указанный период. Сделан вывод, что их целесообразно считать первой волной миграции украинцев на эту территорию. Выявлено, что она была малочисленной, 
a ее члены в основном занимались сельскохозяйственной деятельностью. Раскрыты главные пути прибытия украинцев на австралийский континент: из Западной Украины через Европу и из Восточной Украины через Дальний Восток и Китай. Сделан вывод, что наиболее известным украинцем, который внес значительный вклад в исследование Австралии и Океании, является Н. Миклухо-Маклай. Опровергнуто утверждение российских исследователей о российском происхождении ученого; в противовес, доказано его украинское происхождение. Рассмотрены основные достижения ученого, среди которых не только научное доказательство одинаковой биологической полноценности людей всех наций и рас, а и выступление против расизма и колониализма, стремление добиться от российского правительства установления контроля над этими территориями. Кроме этого, Миклухо-Маклай пытался привлечь европейцев к переезду на постоянное место жительства в Новую Гвинею и посетил с этой целью Киев, Одессу, Петербург и Москву. Выявлены перспективы дальнейших исследований в этой области, в частности это экономическая деятельность и быт первых украинцев в Австралии.

Ключевые слова: Австралия; украинцы; Океания; Н. Миклухо-Маклай.

\section{Вступ}

XV-XVII ст. увійшли в історію як період масштабних піших та морських експедицій. Пошук морських шляхів до Індії та Китаю сприяв відкриттю багатьох континентів і територій, у тому числі, Австралії та Океанії. Перші морські експедиції біля берегів континенту здійснили голландці та іспанці. В.Янсзон у 1605 р. перетнув Торресову протоку і проплив уздовж узбережжя півострова Кейп-Йорк; Тасман у 1642 р. відкрив південно-західну частину Тасманії, яку він вважав частиною материка. Іспанець Торрес у 1606 p. проплив протокою, яка відокремлює від материка острів Нова Гвінея. Однак іспанці та голландці зберегли свої відкриття в таємниці. Через 150 років англієць Дж. Кук «відкрив» східне узбережжя Австралії і оголосив ії володінням Британської корони. На кінець XVIII ст. контури материка в основному були нанесені на карту, однак внутрішні області залишалися «білою плямою», тому з XIX ст. почалася його колонізація.

Загальновідомо, що українці не брали активної участі у відкритті та освоєнні австралійського континенту. Однак серед непересічних особистостей, які зробили вагомий внесок у його дослідження, є етнічний українець, географ, етнограф, антрополог М. Миклухо-Маклай. Імена інших перших українців в Австралії менш відомі, але можна з упевненістю стверджувати, що вони торували шлях для більш потужної хвилі українських мігрантів, які приїхали на континент у др. пол. ХХ ст. Вивчення їх внеску у цей процес становить значний практичний інтерес для України. 


\section{Аналіз останніх досліджень і публікацій}

Дослідженню життя перших українців, що проживали в Австралії y XIX - на поч. XX ст., приділена недостатня увага вітчизняних науковців. Винятком $\epsilon$ постать М. Миклухо-Маклая. Його ім'я можна зустрітив наукових працях, у масовій культурі багатьох країн, в фольклорі тубільців Нової Гвінеї. Зокрема про нього багато пишуть російські науковці, адже дослідник працював під егідою Російської академії наук. Навколо «міфу Маклая» і наукової спадщини дослідника склалася свого роду особлива субдисципліна «маклаєзнавство». На цей момент опубліковано багато біографій науковця, які однак побудовані, переважно, на переказі його новогвінейських щоденників і охоплюють зовсім короткий період життя, адже на острові він прожив загалом трохи більше трьох років.

Серед австралійських дослідників визначимо праці Ф. Грінопа (Greenop, 1944), Є. Вебстера (Webster,1984), Дж. Рассела, Р. Кона (Russell, Cohn, 2012) та ін. 3 огляду на той факт, що більшість родинного архіву Миклухо-Маклая зберігається в Австралії, адже він був одружений із дочкою прем'єр-міністра Нового Південного Уельсу, багато з цих студій базується на оригінальних матеріалах, які залишив науковець. Менша частина архіву Миклухо-Маклая зберігається в Росії. При підготовці біографії вченого багато російських дослідників (А. Клієнтов (Kliyentov, 2007), Б. Путілов (Putilov, 1983), А. Туторський (Tutorsky, Govor, Ballard, 2019) та ін.) використовують ці документи. Однією 3 найбільш грунтовних розвідок, на наш погляд, $\epsilon$ монографія «Два життя білого папуаса» Д. Тумаркіна (Tumarkin, 2012]. Не оминули увагою цю непересічну постать і представники української діаспори в Австралії (В. Антонов-Давидович (Myklukho-Maklay, 1933), П. Вакуленко (Rostek, Vakulenko, 1956; Vakulenko, 1979; Vakulenko, 1952), Д. Чуб (Chub, 1977) та ін.).

Щодо вітчизняних вчених, то відзначимо, насамперед, працю 0. Іванченко «Дорогами Маклая» (Ivanchenko, 1987), у який він спробував не лише відтворити головні події біографії вченого, а й розглянути чинники формування його світогляду, що вплинули на його наукову та громадську діяльність. Цей підхід у своїх дослідженнях розвинули М. Бойчук (Boychuk, 2011), М. Костриця (Kostrytsya, 1996) та ін. Цінним джерелом інформації $\epsilon$ i матеріали, що залишив Миклухо-Маклай: наукові записки і спогади, опубліковані лише після його смерті. Що стосується відомостей про ін. перших українців в Австралії, то короткі відомості про них містяться в енциклопедичних виданнях української діаспори (Shumskyi, 1994; Markus, 1995). 


\section{Виділення невирішених раніше частин загальної проблеми}

Вказане дозволяє констатувати відсутність комплексних праць щодо участі українців у колонізації австралійського континенту.

\section{Формулювання мети і завдань статті}

Тож метою статті є узагальнення існуючої інформації і вивчення першої хвилі української міграції в Австралію (від появи перших поселенців до початку Другої світової війни) та їі ролі у колонізації цієї країни.

\section{Виклад основного матеріалу дослідження}

Точні дані щодо перших українських поселенців в Австралії відсутні. Ймовірно вони прибули на континент у XVIII ст. Зокрема, у 1820 p. до Сіднею причалив російський корабель «Открытие». На його борту знаходився хворий матрос, українець, що народився на Полтавщині, Ф. Зубенко. Можна припустити, що хвороба не дозволила продовжити подорож і він залишився для лікування на березі. Подальша доля цієї людини невідома.

Незабаром на континенті з'явилася низка українських переселенців з Галичини. У 1832 р. до Австралії приїхав лікар зі Львова Джон (ймовірно Іван) Луцький, який працював там державним ботаніком (Shumskyi, 1994, p. 32). У Тасманії проживали К. Кабат та В.Коссак (ймовірно, це прізвище було видозмінено від «Козак»), які перебували на службі в поліції. Також згадується юнак Ю. Горецький зі сполонізованої родини, який прибув 3 Шотландії. Він оселився у м. Джолінг штату Вікторія, а пізніше переїхав до Канади.

У 1850 р. в Австралії з'явився колишній військовий австрійської армії М. Гриб, який мав у власності кілька гектарів землі й організував досить вдалий фермерський бізнес. Він був одинокою людиною, тому вирішив шукати помічників на батьківщині. Він надіслав до свого містечка в Україні два квитки на корабель для тих, хто хотів би приїхати до нього й допомогти по господарству. Через десять років до нього прибув земляк Я. Пелевський, який спочатку допомагав вести справи, а після смерті товариша отримав у спадок його майно. Після його продажу Я. Пелевський переїхав до Австрії і купив там взуттєву фабрику. Ще один українець на прізвище Займак у 1869 р. 3'явився у Брісбені та оселився в Новому Південному Уельсі. Він займався вирощуванням устриць (Shumskyi, 1994, p. 33).

Напередодні Першої світової війни до Австралії почали прибувати українські мігранти, що проживали в Російській імперії і працювали на Далекому Сході та в Китаї переважно на підприємствах кораблебудування і важкої промисловості. Вони оселилися у Квінсі (штат Брісбен) і працювали за фахом або в сільському господарстві. Для налагодження культурного життя вони почали видавати газети «Життя Робітника» та «Знання і Єдність», які через фінансові причини незабаром закрились. 3 огляду на невелику «слов'янську» громаду, українські і російські переселенці спочатку гуртувались 
разом, однак після того, як останні відмовилися замовляти українські газети з Європи та Америки (вочевидь маються на увазі газети української діаспори), розділились. Українці створили невелике об’єднання земляків «Український робітничий клуб». $€$ відомості, що один з його діячів, В. Харченко, організував театральну трупу, яка поставила першу українську виставу в Австралії «Назар Стодоля». Однак труднощі виживання на чужині змусили їх незабаром об'єдналися з російським земляцтвом. 3 огляду на нечисленність української громади, її члени досить швидко асимілювалися (Shumskyi, 1994, p. 35).

У міжвоєнний період в Австралії також проживала низка українців. Інформацію про деяких з них можна знайти в енциклопедичних довідниках, виданих українською діаспорою наприкінці XX ст. Один з них - Г. Піддубний (справжнє прізвище Товмашів) 3 Полтавщини, що перебував у країні в 1913-1917 рр. і працював журналістом. Повернувшись в Україну, він написав низку статей про Австралію. Зокрема у матеріалах, опублікованих у 1930 p. у газеті «Західна Україна», він розповідав, що багато емігрантів в Австралії були робітниками з Далекого Сходу, яким корабельні компанії пропонували подорож до далекого екзотичного краю з високим рівнем цивілізації і життя та гарною заробітною платою. За своїм етнічним складом вони переважно були росіянами та українцями, які оселилися у Квінсленді.

У 1911-1917 рр. в Австралії знаходився відомий більшовицький діяч Артем (Ф. Сергеєв) (Shumskyi, 1994, р. 36), який переховувався в Австралії від російської влади. Тричі відвідував Австралію уродженець Західної України С. Барчинський - лікар, журналіст і любитель пригод. Перший раз у 1912 р., після отримання у Берліні фаху медика. Проживши кілька років в Перті, перед Першою світовою війною він повернувся до Галичини і вступив до лав УГА. Вдруге він відвідав країну в 1936-1939 рр., втретє - у 1946 р. 3 повоєнною хвилею українських мігрантів й оселився там остаточно. Його статті про Австралію неодноразово з'являлася у львівській газеті «Діло» (Markus, 1995, p. 41).

Після революційних подій у Росії в 1917-1920 рр. до Австралії прибув етнічний українець з Сибіру І. Іванець, який організував недалеко від м. Дарвін досить ефективне фермерське господарство. До емігрантів міжвоєнної пори варто віднести й Є. Антоніцина, який приїхав у 1932 р. у Сідней, а потім оселився у Квінсі. У передвоєнний період ще кілька українців, що проживали на Далекому Сході, переїхали на австралійський континент (М. Мережаний, М. Пирогів, Г. Дончак й ін.). Наприклад, Г. Дончак був президентом Української Національної Ради на Далекому Сході. М. Мережаний, уродженець Одещини, залишив Україну в 1924 р., однак діставався до Австралії лише в 1938 р. через поселення українців на Далекому Сході, започатковане в результаті Столипінської аграрної реформи - Сірий Клин. Ймовірно, що таким чином він 
рятувався від більшовицької влади, яку на той час вже було встановлено на території України і Росії. У Брісбені він брав активну участь у громадському житті, зокрема багато років був диригентом хору громади і проповідником української євангельської церкви (Markus, 1995, p. 122).

Окреме місце серед першопрохідців австралійського континенту займає М. Миклухо-Маклай, який походив з козацького роду Миклух. Наразі його родовід та місце народження $\epsilon$ предметом наукового дискурсу. Зокрема багато російських біографів дослідника вважають, що він народився в Росії в колишній Новгородській губернії, однак існують достовірні факти, які спростовують це твердження. Наприклад, у біографії, надрукованій в Австралії у 1882 р., зазначено, що прадід Миклухо-Маклая був сотником Запорізького війська й відзначився в битві за Очаків в 1772 р. Одна зі згадок про цей факт знаходиться в записнику відомого польського шляхтича Л.Замойського, який був особисто знайомим 3 ученим. Ранні польські і австралійські джерела подають, що вчений народився в родинному маєтку в Україні у Малині, а родина батька Миклухи-Маклая походила з Чернігівщини. Батько, закінчивши Ніжинський ліцей та Петербурзький інститут інженерів шляхів, працював деякий час одним із відповідальних будівельників залізниці між Москвою й Петербургом. У родині було п'ятеро дітей (Rostek, Vakulenko, 1956, pp. 3-4).

Д. Чуб у книзі «3 новогвінеських вражень» наводить вислів МиклухоМаклая, надрукований у сіднейській газеті «Сідней МонінгГероальд» у 1884 р.: «Моя особа $є$ прикладом того, як щасливо з'єдналися три одвічно ворожі сили. Палка кров запорожців мирно злилася 3 кров'ю їхніх, здавалося, непримирених ворогів, гордих ляхів, розбавлених кров'ю німців. Я дуже люблю батьківщину мого батька - Україну, але ця любов не применшує поваги до двох вітчизн батьків моєї матері - Німеччини й Польщі» (Chub, 1977, p. 93]. Сукупність цих фактів дозволяє нам констатувати українське походження Миклухо-Маклая й віднести його до українських дослідників Австралії та Океанії.

Спочатку М. Миклухо-Маклай навчався у Петербурзі, а потім переїхав закордон i продовжив навчання $\mathrm{y}$ Гейдельберзькому, Лейпцизькому та Єнському університетах. Навчаючись в останньому, він, як асистент німецького зоолога Ернста Геккеля, побував у наукових експедиціях на Канарських островах, у Франції, Італії, Марокко (Rostek, Vakulenko, 1956, p. 6). Під час цих поїздок він виявив інтерес до культури і побуту корінного населення. Саме це зіграло вирішальну роль у подальшому житті талановитого вченого. У 1871-1883 pp. Миклухо-Маклай здійснив низку наукових експедицій у Папуа Нову Гвінею та Океанію, на Філіппінські острови, острови Малайського архіпелагу, півострів Малакка. За перші п’ять місяців 
проживання у затоці Астролябія Миклухо-Маклай знайшов спільну мову з місцевим племенем папуасів; вони полюбили його і навіть запропонували залишитися у них назавжди (Rostek, Vakulenko, 1956, pp. 9-10). Найдовше він жив у Новій Гвінеї, приїжджаючи на острів тричі між 1871 та 1883 рр. Саме тут він створив свою відому працю «Серед дикунів Нової Гвінеї» (Myklukho-Maklay,1933). Усього ж він написав понад 160 наукових праць, присвячених різним питанням етнографії, антропології, порівняльної анатомії, метеорології, географії, зоології та загалом здійснив десять експедицій до Нової Гвінеї, Філіппін, Малакки, Австралії, Меланезії, Мікронезії.

За своє коротке життя дослідник зробив низку відкриттів у різних наукових дисциплінах. Можна стверджувати, що в галузі фізичної антропології та етнології Миклухо-Маклай відкрив зовнішньому світу папуасів Берега Маклая (північно-східна частина Нової Гвінеї), провівши грунтовне дослідження їх антропологічного типу, матеріальної культури, господарського ладу і суспільного життя.

Під час другої експедиції на Малакський півострів (1875) МиклухоМаклай став першовідкривачем сенойских племен семелай і темок, а також невеликого семангського племені батак, що представляє господарськокультурний тип бродячих мисливців і збирачів. Він уперше описав морські тераси на північно-східному узбережжі Нової Гвінеї і виявив причини їхутворення, зробивши цим значний внесок у вивчення геоморфології і тектоніки цього регіону (Tumarkin, 2012,p. 29).

Важливим результатом наукових досліджень Миклухо-Маклая став його висновок про те, що не існує різниці між представниками різних людських рас, а соціально-культурні відмінності, такі як ступінь розвитку і цивілізованості, обумовлені навколишнім середовищем народів.

Миклухо-Маклай не обмежувався тільки наукою. Він турбувався, що перегони Голландії і Англії за колонії в Океанії закінчаться колонізацією західних і південних берегів Нової Гвінеї та визиском тубільців. Принижене становище корінного населення Нової Гвінеї і островів Тихого Океану не полишало його байдужим: він боровся 3 несправедливістю усіма доступними йому засобами, посилаючи прохання губернаторам колоній, наполегливо звертаючи їхню увагу на факти насильного захоплення земель і випадки рабства. Він відчував власну відповідальність за тубільне населення цієї місцевості і прагнув його захистити від неминучості колонізації. Розуміючи, що Росія не мала колоніальних замірів відносно Нової Гвінеї, Миклухо-Маклай навіть звертався через посередництво Російського географічного товариства 3 проханням до російського уряду взяти цю територію під свою опіку. Учений розробив проєкт створення у Папуа Новій Гвінеї незалежної держави - папуаського Союзу і організації на цій 
території вільної російської колонії, але російський цар Олександр III відкинув цей проєкт (Rostek, Vakulenko, 1956, p. 4).

У 1878 р. Почався австралійський період життя Миклухо-Маклая; він оселився у Сіднеї. Наукові кола цього міста прийняли його прихильно й він швидко включився в дослідницьку діяльність із порівняльної анатомії в приватному музеї сера Вільяма Меклея, голови Наукового товариства Ліннея Нового Південного Уельсу. 3 огляду на відсутність відповідних умов у місцевих музеях, він лобіював ідею необхідності створення окремої лабораторії для дослідження морських істот (Russell, Cohn, 2012, p. 55). y результаті його наполегливості і активної участі в збиранні грошей на цю мету, в 1881 р. була створена перша лабораторія морської біології в Австралії, розташована у затоці Ватсон. Миклухо-Маклай працював у ній певний час. Під час проживання у Сіднеї в 1883-1886 pp. він продовжував відстоювати права папуасів, боровся проти колоніального розділу Нової Гвінеї, анексії Берега Маклая кайзерівською Німеччиною, виступав проти расизму і колоніалізму. 3 цим питанням він навіть звертався до Державного секретаря Британії у справах Індії лорда Дербі (Putilov, 1983, p. 168).

Закохопившись Австралію й Океанію, під час своєї подорожі в Росію і Західну Європу у 1882-1883 рр. він намагався заохотити людей до переїзду на постійне місце проживання у Нову Гвінею. 3 цією метою він відвідав Київ, Одесу, Петербург і Москву. В Москві після доповіді Маклая про Нову Гвінею було навіть створено «Товариство Тихого Океану».

\section{Висновки}

Отже, можна зробити висновок, що перша хвиля української міграції на австралійський континент тривала 3 поч. XIX ст. по поч. Другої світової війни. Українці прибували двома шляхами - із Західної України через Європу i зі Східної України через Далекий Схід і Китай. 3 огляду на незначну чисельність, вони створювали спільні з ін. слов'янськими мігрантами громади, найчастіше - з росіянами. Не дивлячись на це, їх можна вважати українськими першопрохідцями на австралійському континенті. Особливе місце серед них займає М. Миклухо-Маклай, який мав українське походження.

Перспективою подальших досліджень може стати більш глибокий аналіз життя і побуту перших українських переселенців в Австралії, зокрема їхнього культурного та економічного життя.

\section{References:}

1. Boychuk, M. I. (2011). Lytsar humanizmu: Mykola Mykolayovych MyklukhoMaklay [The Knight of Humanism: Nikolai Miklukhoi Maclay]. Chernihiv: Chernihivs'kioberehy. 
2. Chub, D. Z. (1977). Z Novohvineiskykh vrazhen na slidakh Myklukhy-Maklaia [From New Guinea impressions in the footsteps of Miklukha-Maklay]. Australia: Melbourne.

3. Greenop, F. S. (1944). Khto podorozhyje odun [Who travels alone]. Sydney: K G Murray.

4. Ivanchenko, O. S. (1987). Dorohamy Maklaya [On the roads of Maclay]. Kyiv: TSK LKSMU “Molod” Publishing.

5. Kliyentov, A. (2007). Nikolay Miklukho-Maklay [NikolaiMiklukho-Maclay]. Moscow: Belyygorod.

6. Kostrytsya, M. Y. (1996). Ukrayiny ne soromyvsya, Ukrayinoyu - hordyvsya: Myklukho-Maklay i Ukrayina [Ukraine is not shy: Ukraine is proud of: MiklukhoMaklay and Ukraine]. Zhytomyr; Malyn.

7. Markus, V.V., ed. (1995). Entsyklopediya Ukrayins'koyi Diaspory [Encyclopedia of the Ukrainian Diaspora]. (1995). Vol. 4: Avstraliia - Aziia - Afryka. Kyiv: Shevchenko Scientific Society, National Academy of Sciences of Ukraine.

8. Myklukho-Maklay, M. M. (1933). Sered dykuniv Novoyi Hvineyi [Among the savages of New Guinea]. Kharkiv-Odesa: Molodyy bil'shovyk.

9. Putilov, B. N. (1983). Mykolay Myklukho-Maklay: mandrivnyk, naukovets, humanist [Nikolai Miklouho-Maclay: Traveller, Scientist and Humanist]. Moscow: Progress.

10. Rostek, L., Vakulenko, P. (1956). Mykola Myklukho-Maklay. 150 rokiv z dnya narodzhennya [Miklukho-Maklay: 150 years since birth]. Adelaide: Ukrainian Museum in Adelaide.

11. Russell, J., Cohn, R. (2012). Nikolas Myklukho-Maklay [Nicholas MiklouhoMacLay]. Book on Demand Ltd.

12. Shumskyi, V., eds. (1994). Al'manakh ukrayins'koho zhyttya $v$ Avstraliyi [Analmanac of Ukrainian life in Australia]. Sidney: "Vil'na dumk"»; Fundatsiya Ukrayinoznavchykh Studiy Avstraliyi.

13. Tumarkin, D. D. (2012). Myklukho-Maklay. Dve zhizni "belogo papuasa" [Miklouho-Maclay: two lives of a white Papuan]. Moscow: Molodaya gvardiya.

14. Tutorsky, A.V., Govor, E., Ballard, C. (2019). Spadshchyna MikloukhoMaklaya v naukovykh doslidzhennyakh rosiys'koyi ta anhliys'koyi movy 19922017[Miklouho-Maclay's Legacy in Russian and English-Language Academic Research, 1992-2017]. Archaeology, Ethnology \& Anthropology of Eurasia, Vol. 47/2, pp. 112-121.

15. Vakulenko, P. (1952). V dzungliah Novoji Gvineji: zhyttia i pryhody ukrainskoho doslidnyka Myklukhy-Maklaya [In the jungle of New Guinea: the life and adventures of the Ukrainian explorer Miklukho-Maclay]. Adelayida: "Yednist'" Puvlishing. 
16. Vakulenko, P. (1979). Papua Nova Gvineya [Papua New Guinea]. Adelayida: "Avstraliyana" Ukrainian Publishing House.

17. Webster, E. M. (1984). Liudyna-Misiats [The Moon Man]. Carlton: Melbourne University Press.

(C) Перга Т. Ю., 2020 